\title{
AN ANALYSIS PROCEDURE FOR AMERICIUM IN ENVIRONMENTAL SAMPLES
}

ROBERT W. HOLLOWAY AND

DAVID W. HAYES

TIS FILE、 RECORD COPY

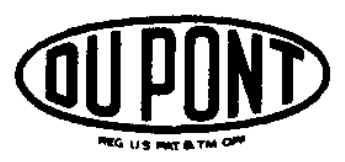

E. I. du Pont de Nemours \& Co. Savannah River Laboratory Aiken, SC 29808 


\section{DISCLAIMER}

This report was prepared by E. I, du Pont de Nemours and Company (Du Pont) for the United States Department of Energy under Contract DE-AC09-76SR00001 and is an account of work performed under that Contract. Neither the United States, the United States Department of Energy nor Du Pont, nor any of their employees, makes any warranty, express or implied, or assumes any legal liability or responsibility for the accuracy, completeness, or usefulness of any information, apparatus, product, or process disclosed herein, or represents that its use will not infringe privately owned rights. Reference herein to any specific commerical product. process, or service by trade name, mark, manufacturer, or otherwise does not necessarily constitute or imply endorsement, recommendation, or favoring of same by Du Pont or by the United States Government or any agency thereof. The views and opinions of authors expressed herein do not necessarily state or reflect those of the United States Government or any agency thereof.

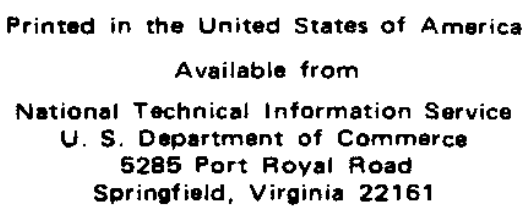

Price: Printed Copy A02; Microfiche AO1 
Distribution Category: UC-4

\section{AN ANALYSIS PROCEDURE FOR AMERICIUM IN ENVIRONMENTAL SAMPLES}

ROBERT W. HOLLOWAY AND DAVID W. HAYES

Approved by

T. V. Crawford

Environmental Sciences Division

Publication Date: January 1982

E. 1. du Pont de Nemours \& Co. Savannah River Laboratory Aiken, SC 29808 
Several methods for the analysis of $241_{\mathrm{Am}}$ in environmental samples were evaluated and a preferred method was selected. This method was modified and used to determine the $241_{\text {Am }}$ content in sediments, biota, and water. The advantages and limitations of the method are discussed. The method is also suitable for ${ }^{244} \mathrm{Cm}$ analysis. 


\section{CONTENTS}

Introduction 7
Method Selection and Development 7
Americium Determination 9
Sample Preparation 9
Oxalate Precipitation 9
Plutonium/Thorium Removal 11
Polonium, Lead, and Bismuth Removal 11
Americium/Neodymium Separation 12
Electrodeposition 12
General Comments 13
References 16




\section{AN ANALYSIS PROCEDURE FOR AMERICIUM IN ENVIRONMENTAL SAMPLES}

\section{INTRODUCTION}

Although the behavior of plutonium in the environment has been studied quite extensively, there is comparatively little information available on the environmental behavior of americium. Both ${ }^{239} \mathrm{Pu}$ and $24 \mathrm{l}_{\mathrm{Am}}$ are present on a worldwide basis as the result of nuclear weapons testing in the atmosphere. However, it is known that $241_{\mathrm{Am}}$ is not produced directly in the nuclear explosion but is derived from the beta decay of $241 \mathrm{Pu}$ ( 13 year half-life). Accordingly, it is expected that the $241_{\mathrm{Am}} / 239,240 \mathrm{Pu}$ dpm ratio is near zero in fresh fallout and increases to a maximum of 0.40 in fallout that is several decades old.1

Since the expected concentration of ${ }^{241} \mathrm{Am}$ in aquatic systems receiving only nuclear weapons fallout is near the detection limits and less than the plutonium concentration levels, the analytical method chosen to measure americium in environmental samples must be highly efficient in removing unwanted radioactive contaminants. Such contaminants may interfere with the determination of $241 \mathrm{Am}$ if their alpha decay energy is near the $5.48 \mathrm{MeV}$ peak of $241_{\mathrm{Am}}$ or near the $5.27 \mathrm{MeV}$ peak of the $243 \mathrm{Am}$ tracer.

Since other transplutonium actinides are chemically similar to americium, interference from those nuclides is possible. As a practical matter, the only transplutonium nuclide detectable in the environment on a global basis is $241 \mathrm{Am}$, and thus the possible interference from other transplutonium nuclides is not a problem. The natural radioactive nuclides are present in easily detectable amounts, and an effective americium method must be able to remove these natural contaminants.

\section{METHOD SELECTION AND DEVELOPMENT}

The literature offered a number of available methods for the determination of americium. A common disadvantage of all the available methods for the determination of americium is the greater amount of time and labor required for the americium analysis compared to plutonium. This is due in part to the fact that americium in aqueous solutions exists on $1 y$ in one oxidation state $(+3)$. For plutonium, the existence of several oxidation states (especially +3 and +4 ) permits a very effective and rapid purification by means of various types of chromotography. In a typical plutonium procedure, plutonium is purified by quantitatively converting the plutonium 
to the +4 state where it forms an anionic nitrate complex in nitric acid. The complex is absorbed very strongly by anion exchange resins while the impurities are removed in the liquid phase. The plutonium can be removed from the resin column by reduction to $\mathrm{Pu}^{+3}$. In contrast, americium is not absorbed by anion exchange resins in acid solutions. A large number of other elements found in the environment behave similarly to americium with respect to anion exchange resins and thus the rapid method used for plutonium cannot be used for americium.

Although solvent extraction techniques exist for both plutonium and americium, the methods using ion exchange resins have become the most common method for plutonium. Americium is analyzed so infrequently in the environment that there is no clear choice as the most popular method. Since ion exchange resins appear to have significant advantages in terms of ease of handling, a method based on ion exchange resins was sought for the americium analysis.

of the published methods, several were rejected without laboratory evaluation, because of extreme complexity. The two methods chosen for laboratory evaluation are described below.

Method 1. Determination of americium by ion exchange in a nitric acid-methanol medium. This method was published by Holm and Fukai. 2 The unique feature of this method is the sorption of americium on Dowex ${ }^{\otimes}$ (Dow Chemical Co.) 1 x 8 anion exchange resin in $1 \mathrm{M} \mathrm{HNO}_{3}-90 \%$ methanol solution followed by washing of the column with the same solution. Americium is then eluted from the column with $0.5 \mathrm{M} \mathrm{HNO}_{3}-70 \%$ methanol mixture. Other portions of the procedure remove iron, plutonium, and thorium by ion exchange columns. This method gave good yields of americium tracer in some cases but was judged less reliable than the other method because of occasional total losses of the tracer. In addition, the method cannot reliably be used to determine curium simultaneously since separation of the americium and curium tracers was observed. This is contrary to the report of Holm and Fukai ${ }^{2}$ who state that the method can be used for the simultaneous analysis of americium and curium. Americium and curium ordinarily cannot be separated except by the use of methods specifically designed for such a separation. However, since one of the tehniques for separating americium and curium involves the use of methanol-nitric acid mixtures, it is not surprising that fractionation occurs with this method. For these reasons this method was not selected for use in the environmental study.

Method 2. The ammonium thiocyanate method. This method was described by Bojanowski, et al. 3 and is similar to the procedure used earlier by Keenan ${ }^{4}$ to purify milligram amounts of $241_{\mathrm{Am}}$. The distinguishing feature of this method is the purification of americium as the thiocyanate complex on Dowex ${ }^{\circledR} 1$ X 8 anion exchange 
resin. Dther parts of the procedure such as sample preparation are common to many other methods. This method was selected as the best available method for environmental samples. As the work progressed, a number of changes were made as needed. The following procedure is the final modified version and includes standard sample preparation techniques.

\section{AMERICIOM DETERMINATION}

The out line of the procedure is given in Figure 1.

\section{Sample Preparation}

Sediment samples are freeze-dried to remove water and then ashed at $470^{\circ} \mathrm{C}$. The resulting ashed sample is a dry powder. If the sample is ashed without freeze drying, it becomes brick-like and more difficult to process. Biological samples are also ashed and prepared in the same way except for the omission of freeze drying. Water samples can be concentrated using the manganese dioxide method of Wong. 5 The resulting cartridges are ashed and processed in the same way as sediments and biota. It should be noted that manganese dioxide weights of greater than four grams cause severe problems with this method. The americium tracer is often lost in these cases. If the manganese dioxide weight is below four grams, good results can be obtained.

After ashing of the sample, a 6 to $10 \mathrm{gram}$ portion of the sample is weighed and spiked with $0.3 \mathrm{dpm}$ of $243 \mathrm{Am}$ tracer and $40 \mathrm{mg}$ of neodymium carrier. The sample is then leached three times with $8 \mathrm{M} \mathrm{HCl}$ ( $70 \mathrm{~mL}$ ) with each portion boiled for 30 minutes before separation of the liquid. Centrifugation may be necessary to separate the remaining solids. The three liquid fractions are combined and evaporated to dryness. The dry residue is dissolved in 10-20 mL of $8 \mathrm{M} \mathrm{HNO}_{3}$ and diluted to $2 \mathrm{~L}$ with water. The sample is now ready for oxalate precipitation.

\section{Oxalate Precipitation}

After the sample is diluted to $2 \mathrm{~L}$ as indicated above, the $\mathrm{pH}$ is carefully adjusted to 2 with $1 \mathrm{M} \mathrm{N} \mathrm{NH}_{4} \mathrm{OH}$, and oxalic acid is added so that the solution is $5 \%$ oxalic acid. The neodymium oxalate should form at this point, although it may require up to an hour to form. The precipitate should be allowed to stand overnight, and the supernate can then be decanted off without centrifuging. The precipitate is washed with $0.5 \%$ oxalic acid and then dissolved in as little $8 \mathrm{M} \mathrm{HNO}_{3}$ as possible. If calcium is present a large fraction of the precipitate will be calcium oxalate. 


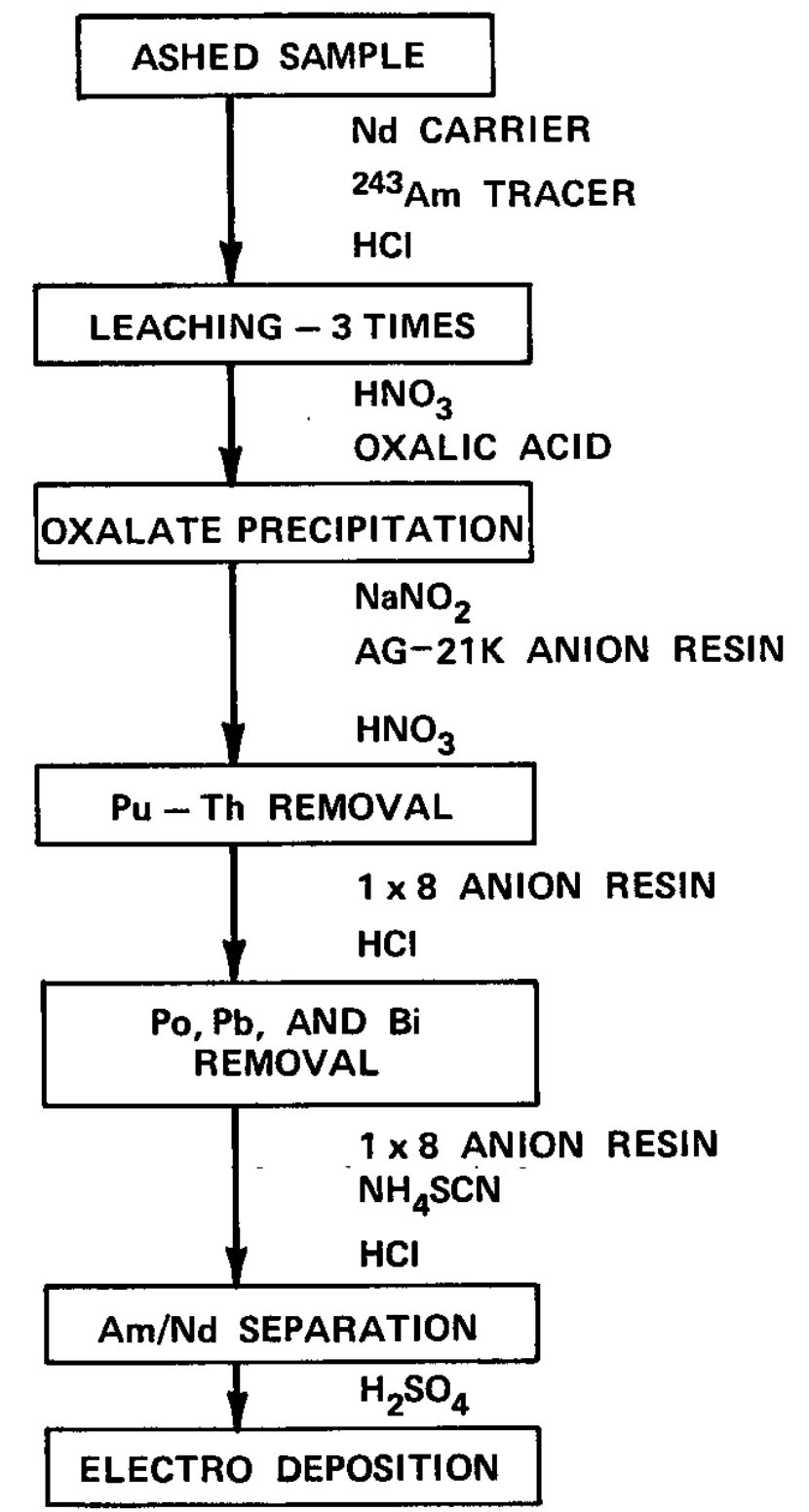

FIGURE 1. Outline of Am-Cm Procedure 
The use of $1 \mathrm{M} \mathrm{NH} 4 \mathrm{OH}$ rather than $14 \mathrm{M} \mathrm{NH} 4 \mathrm{OH}$ helps to reduce the coprecipitation of calcium, but if the ash contains bones some calcium oxalate will precipitate. The neodymium oxalate tends to precipitate at a lower $\mathrm{pH}$ so careful adjustment of pi to $\mathrm{pH} 2$ is also helpful.

After the precipitate is dissolved in $8 \mathrm{M} \mathrm{HNO}_{3}$, the volume is adjusted to $200 \mathrm{~mL}$ and the $\mathrm{pH}$ is again brought to $\mathrm{pH} 2$ with $\mathrm{NH}_{4} \mathrm{OH}$. To ensure good precipitation, an equal volume of saturated oxalic acid is added. Precipitation will usually occur before the addition of the oxalic acid.

The precipitate is then centrifuged and the supernate discarded. After washing with $0.5 \%$ oxalic acid, $10 \mathrm{~mL}$ of $10 \mathrm{M} \mathrm{NaOH}$ is added and the mixture is allowed to stand for five minutes. This converts the neodymium oxalate to the hydroxide. Calcium oxalate does not convert to the hydroxide. The sample is diluted with water and centrifuged. Discard the supernate, add a few drops 10M $\mathrm{NaOH}$, dilute with water and centrifuge again. Discard the supernate and dissolve the hydroxides in $20 \mathrm{~mL} 8 \mathrm{M} \mathrm{HNO} 3$. If any precipitate remains after the addition of the nitric acid, it should be separated from the supernate, washed with $20 \mathrm{~mL}$ of $8 \mathrm{M} \mathrm{HNO}_{3}$ and the two liquid portions combined. Any residue can be discarded.

\section{Plutonium/Thorium Removal}

To the $8 \mathrm{M} \mathrm{HNO}_{3}$ containing the sample, add 0.1 gram of $\mathrm{NaNO}_{2}$ and let stand five minutes. This converts plutonium to the quadrivalent state for removal on the anion exchange column. The solution is then passed through a $20 \mathrm{~cm}$ column containing AG-21K anion exchange resin, 50-100 mesh, conditioned with $50 \mathrm{~mL}$ of $8 \mathrm{M} \mathrm{HNO}_{3}$. Americium and neodymium pass through the column which is then washed with $50 \mathrm{~mL} 8 \mathrm{M} \mathrm{HNO}_{3}$ and the wash added to the eluate. Plutonium and thorium are absorbed by the resin. The nitric acid containing the sample is evaporated to dryness, and the residue is dissolved in $20 \mathrm{~mL} 8 \mathrm{M} \mathrm{HNO}_{3}$. The plutonium/thorium removal step is repeated using fresh $21 \mathrm{~K}$ resin. If samples with extremely low americium levels are being analyzed, it is advisable to use a third cycle of plutonium/thorium removal.

\section{Polonium, Lead, and Bismuth Removal}

The nitric acid solution is evaporated to dryness. The residue is dissolved in a few $\mathrm{mL}$ of concentrated $\mathrm{HCl}$ and evaporated to dryness. Repeat this step. Distilled water is added and the sample is taken to dryness twice. The sample is dissolved in $10 \mathrm{~mL} 1.5 \mathrm{M}$ $\mathrm{HCI}$ and passed through a 1 × 8 anion exchange column (20 cm) that has been conditioned with $50 \mathrm{~mL}$ of $1.5 \mathrm{M} \mathrm{HCl}$. The column is washed 
with two column volumes of $1.5 \mathrm{M} \mathrm{HCl}$ and the washings are combined with the samples.

\section{Americium/Neodymium Separation}

The sample is evaporated to dryness and the residue is dissolved in $5-10 \mathrm{~mL}$ of $6 \mathrm{M} \mathrm{NH} 4 \mathrm{SCN}$. $\mathrm{NH}_{4} \mathrm{OH}$ (1M) is added dropwise until the pink color (due to traces of iron) disappears. The color is restored by dropwise addition of $0.2 \mathrm{M} \mathrm{HCl}$. The solution should be slightly pink and the $\mathrm{pH}$ should be between 2 and 5 at this point. The solution is transferred to the top of a 1 X 8 (100-200 mesh) anion exchange column of $20 \mathrm{~cm}$ length. The column is conditioned previously with $100 \mathrm{~mL} 4 \mathrm{M} \mathrm{HC} 1,150 \mathrm{~mL} 0.01 \mathrm{M} \mathrm{HC} 1$ and $50 \mathrm{~mL}$ $2 \mathrm{M} \mathrm{NH} 4 \mathrm{SCN}$ in that order. After the sample is added to the column, the neodymium carrier is eluted with $150 \mathrm{~mL}$ of $2 \mathrm{M} \mathrm{NH}_{4} \mathrm{SCN}$ and is discarded. Americium is retained by the resin and is then removed with $80 \mathrm{~mL}$ of $4 \mathrm{M} \mathrm{HCl}$. The portion that elutes with the $4 \mathrm{M} \mathrm{HC} 1$ is allowed to drip into $15 \mathrm{~mL}$ of concentrated nitric acid. This destroys the $\mathrm{NH}_{4} \mathrm{SCN}$ in a reaction that produces small amounts of sulfuric acid and is exothermic. Since only the first column volume eluted will contain substantial $\mathrm{NH}_{4} \mathrm{SCN}$, the reaction is much more vigorous at the beginning of the elution. Precautions should be taken to insure that the reaction proceeds only by dropwise addition of the eluting solution and with constant stirring. The reaction is much too vigorous if more than one drop of $2 \mathrm{M} \mathrm{NH}_{4} \mathrm{SCN}$ is allowed to react with the nitric acid. There is also a time delay before the start of the reaction after the first drop is added. The column should be turned off at this point until the first drop visibly reacts with the nitric acid.

The solution resulting from the above reactions is evaporated until only sulfuric acid remains and is then heated strongly until the sulfuric acid is volatilized. It is helpful if the last part of the evaporation is done in a $50 \mathrm{~mL}$ beaker so that the sample will cover a smaller area and make dissolving easier. The sample is taken to dryness again with a few $\mathrm{mL}$ of concentrated $\mathrm{HCl}$. It is then dissolved in $6 \mathrm{M} \mathrm{NH} 4 \mathrm{SCN}$ as before and the $\mathrm{NH}_{4} \mathrm{SCN}$ column cycle is repeated to remove the last traces of neodymium. While two cycles will often remove virtually all of the neodymium carrier, it was found that three cycles were necessary to ensure consistent quality of the electroplated disk containing the americium. Any neodymium not removed by these columns will electroplate with the americium and degrade the resolution of the alpha spectrum.

\section{Electrodeposition}

The solution from the last $\mathrm{NH}_{4} \mathrm{SCN}$ column is evaporated until only sulfuric acid remains. Any ammonium salts are destroyed by 
addition of $12 \mathrm{M} \mathrm{HCl}$ and $16 \mathrm{M} \mathrm{HNO}_{3}$. The sulfuric acid is evaporated until only $0.2-0.4 \mathrm{~mL}$ remain. After cooling, $5 \mathrm{~mL}$ of water is added and also a few drops of thymol blue indicator. The sample is made basic with $0.6-1.0 \mathrm{~mL} 14 \mathrm{M} \mathrm{NH}_{4} \mathrm{OH}$ and is then neutralized to a faint pink color with $18 \mathrm{M} \mathrm{H}_{2} \mathrm{SO}_{4}$. The solution is transferred to a plating cell where the $\mathrm{pH}$ is adjusted to 2-3. The final volume should be 10-15 mL. The sample is then electroplated for two hours at one ampere. Before turning off the current, $1 \mathrm{~mL}$ of $14 \mathrm{M} \mathrm{NH} \mathrm{NH}_{4} \mathrm{OH}$ is added and allowed to $\mathrm{mix}$ for one minute. This prevents the americium from being removed by the acid solution when the current is off. The current is then switched off and the plated disk is washed with distilled water and acetone. The sample is then ready for counting by alpha spectrometry.

\section{General Comments}

As with most americium procedures, this method requires more time than plutonium procedures. It would be highly desirable to reduce the time required but there is currently no method that is significantly shorter. A possible labor saving modification would be to omit the neodymium carrier and reduce the number of thiocyanate columns to one. However, there are indications that the behavior of trace amounts of americium is not consistent when it is carrier-free. When an additional $8 \mathrm{M} \mathrm{HNO} 3$ column was inserted at points in the procedure where the sample was free of carrier, the americium was almost invariably lost. In addition, the oxalate precipitation step is useful as a preliminary purification step and is not possible without a carrier. The carrier has the additional advantage of being visible until the last stages of the procedure so that reasons for low yields can be more easily determined.

Although the tracer yields obtained using this method are often $80-90 \%$, low yields of $10-20 \%$ sometimes occur if the sample has bones or other sources of calcium.

The natural alpha-emitter, ${ }^{228} \mathrm{Th}$ is sometimes a source of contamination since its alpha energy is very similar to that of $241 \mathrm{Am}$. The presence of ${ }^{228} \mathrm{Th}$ can be confirmed by the presence of its daughter, ${ }^{224} \mathrm{Ra}$, which has an alpha energy that is not obscured by the americium peaks. For this reason, the presence and approximate amount of any ${ }^{228} \mathrm{Th}$ contamination is easily determined.

Some typical results for $241_{\text {Am }}$ obtained by this method are given in Table I. If $244 \mathrm{Cm}$ is present at detectable levels, it may also be determined from the same spectrum, Figure 2. In such cases the americium tracer may serve as a tracer for $244 \mathrm{Cm}$. This can be seen in the consistency of the three curium values for Four Mile Creek and is the expected result based on the chemical similarity of the two elements. 
TABLE I

Typical Americium and Curium Determinations Using the Thiocyanate Method
$241_{\text {Am }}$ Concentration, $\mathrm{fCi} / \mathrm{L}$
$244 \mathrm{Cm}$ Concentration, $\mathrm{ECi} / \mathrm{L}$

Four Mile Creek Water Samples
Sample 1
$4.5 \pm 0.3$
$7.4 \pm 0.4$
Sample 2
$5.1 \pm 0.2$
$7.9 \pm 0.3$
Sample 3
$5.5 \pm 1.0$
$7.2 \pm 1.1$

Newport River Estuary

$\begin{array}{lll}\text { Oysters } & 0.30 \pm 0.05 \mathrm{fCi} / \mathrm{g} & \text { N.D.* } \\ \text { Pinfish } & <0.07 \mathrm{fCi} / \mathrm{g} & \text { N.D.* } \\ \text { Spot } & 0.06 \pm 0.02 \mathrm{fCi} / \mathrm{g} & \text { N.D.* } \\ \text { Mullet } & <0.07 \mathrm{f} \mathrm{Ci/g} & \text { N.D.* }\end{array}$

* $244 \mathrm{Cm}$ is far below detection limits if the only source is fallout. The curium and virtually all of the ${ }^{241} \mathrm{Am}$ in Four Mile Creek is from SRP operations. 


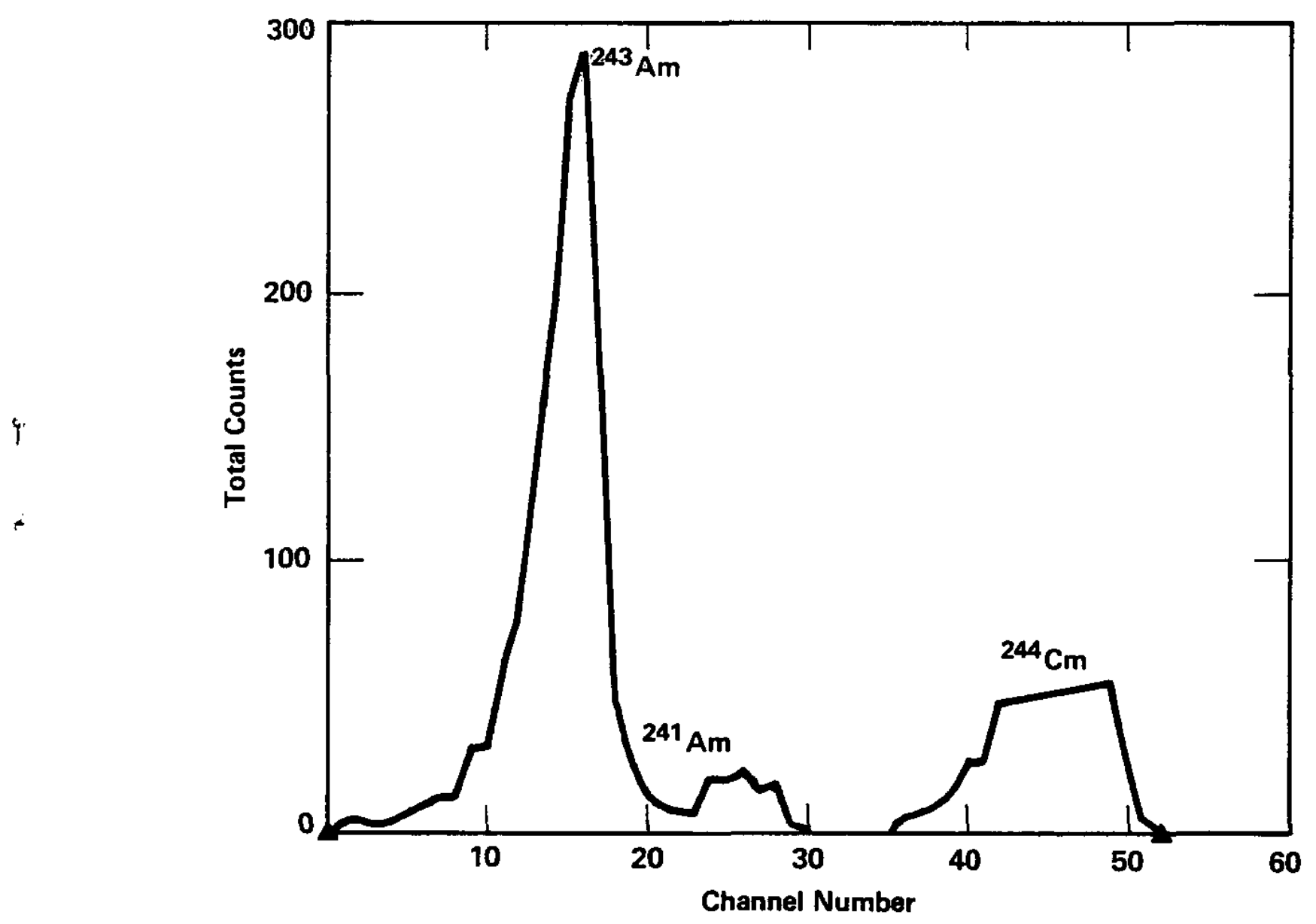

FIGURE 2. Alpha Spectrum of Four Mile Creek Water 
1. R. W. Perkins and C. W. Thomas. "Worldwide Fallout." in Transuranic Elements in the Environment, DOE/TIC-22800, p 53, Springfield, VA (1980).

2. E. Holm and R. Fukai. "Determination of Americium and Curium by Using Ion-Exchange in Nitric Acid-Methanol Medium for Environmental Analysis." Talanta 23, 853 (1976).

3. R. Bojanowski, H. D. Livingston, D. L. Schneider, and D. R. Mann. "A Procedure for Analysis of Americium in Marine Environmental Samples." Reference Methods for Marine Radioactivity Studies II IAEA, P. 77, Vienna (1975).

4. T. K. Keenan. "Rapid and Efficient Purification of Americium." J. Inorg. Nucl. Chem. 20, 185 (1961).

5. K. M. Wong, G. S. Brown, and V. E. Noshkin. "A Rapid Procedure for Plutonium Separation in Large Volumes of Fresh and Saline Water by Manganese Dioxide Coprecipitation." J. of Radioanalytical Chemistry 42, 7 (1978). 